\title{
Henry Dwight Chapin: Pioneer in the study of institutionalized infants
}

\author{
PHILIP HOWARD GRAY \\ Montana State University, Bozeman, Montana
}

\begin{abstract}
At the turn of the century, infant mortality in American institutions for infants approached 100\%. Policies initiated by Henry Dwight Chapin emphasized the placement of children in "boarding out" homes as quickly as possible and an increase in social attention paid to the infants that remained in the institutions. Chapin was evidently the first behavioral scientist who employed statistical procedures to uncover a critical period for social development in institutionalized infants. His evidence suggested overwhelmingly that the 1st year of life is the most critical when normal conditions of childrearing are replaced by a state of social deprivation, and that the first 6 months are more important than the second 6 months. While his influence in the history of child psychology has virtually been forgotten, citation analysis suggests an increasing awareness of his scientific importance.
\end{abstract}

At the turn of the century, infant institutions were places where the doomed were temporarily housed. A reduction of the mortality rate came about because of policies initiated by Henry Dwight Chapin, whose statistical studies revealed a criticality for social development during the 1 st year of age.

Chapin was born on February 4, 1857 in Steubenville, Ohio. He was descended from the Puritan colonist Samual Chapin (Anon., 1944). The paradox of the Puritan nature is to be righteous while enjoying success, as Chapin's biographer noted, adding that if Chapin seemed the authentic image of the successful mid-Victorian gentleman, he was actually anything but simple, demanding for himself the right of freedom of inquiry as he was relentlessly driven to do as much as possible for the society that gave him a chance to be effective (Pease, 1957).

\section{Reforming the Institutional Environment}

After graduating from medical school, Chapin served his internship at a leper colony on Ward's Island. No clue exists to show why he became interested in children, but as soon as his internship at the leper colony was over, he began to specialize in the diseases of children. He soon became professor and director of pediatrics at the Columbia Medical School (Pease, 1942). Eschewing the comfortable living of a physician to upper-class children, Chapin turned his attention to the immigrant wretched, noting that the foreign population contributed nearly threefifths of all the paupers in the north Atlantic area (Chapin, 1892). The great waves of recent immigration, especially of those who were landless and impoverished, had created

This paper on Chapin follows a presentation given at the American Psychological Association convention in Washington, DC in 1986. I wish to thank Harold Bauer, who helped me dig out references, and the University of Manitoba, which provided a helpful faculty grant. Reprint requests should be sent to Philip Howard Gray, Department of Psychology, Montana State University, Bozeman, MT 59717. overcrowding and squalor. These conditions, plus the affliction of drunkenness which was common among the immigrants, were the primary causes of the misery that Chapin so often witnessed.

Chapin was convinced that infants engendered harm merely as a result of institutionalization. As early as 1890 , he inaugurated the first hospital social service in the United States, establishing a link between the hospital's baby wards and the home. He emphasized to his staff that each child should be treated as if the staff member were a parent at the child's bedside. His social concern was not restricted to infants. From 1909 to 1920 he served as president of the Working Women's Protective Union, which was organized to provide legal service for those who found themselves imposed upon (Pease, 1957).

When Chapin began practicing in 1885 , the infant mortality rate in New York city was 273 per thousand (Pease, 1957). The area in which he elected to serve was a slum, where sheds on brewery lots housed cows that were kept alive on discarded beer mash. The milk from these starving animals was used to feed the neglected infants of the area. In an attept to obtain wholesome milk, Chapin was frustrated, and when he heard of the discovery of a new grape sugar in Germany he figured out a way to duplicate it at a reasonable cost so that it could be used to feed the infants in his baby wards (Pease, 1957).

Chapin expressed grave doubts that neglected children could attain their full development in adulthood. He insisted that the life of the child was the most valuable asset of the nation, noting that the slums seemed designed to defeat every altruistic effort. He also believed that the hospital environment was no more congenial to the child's welfare than the slum home from which the child came. Thus, as early as 1891 , Chapin began to change the atmosphere of the wards under his direction at the medical school that is now part of Columbia University (see Chapin, 1894, 1908a). Working under the motto that happy children will get well more easily and more cer- 
tainly than unhappy, lonesome children will, Chapin altered the life in the wards so that they "began to take on color and were in a constant state of cheerful disorder," as Pease (1957) has put it.

\section{The Foster Home Movement}

Even with these changes, Chapin felt that infants should be institutionalized only briefly, and that individual supervision of the child would be far better than the collective life of the institution. Acting on that idea, he began a boarding-out system in 1902, with hospitalized infants being placed with selected private families (see Chapin, 1908b). This program, which was inaugurated in Morristown, New Jersey, took its name-the "Speedwell Society"-from a street where one of the first infants was placed. Each child was kept in the boarding home until there it showed permanent improvement; then the child would be returned to its own home, or to the hospital if it was obvious that the case was hopeless. By 1908, 24 families had been employed for 817 children from under 3 months of age to over 5 years. According to Chapin, most of these children would have died had they remained in the hospital. As it was, 103 did succumb despite the improved care, but the distribution of deaths is interesting in light of what we know about human imprinting (see Gray, 1958; Gray \& Gray, 1988). Of those under 3 months of age, 45 died; of those from 3 to 6 months, 29 died; of those from 6 to 12 months, 21 died. Of the children above the age of a year, only 8 died (see Chapin, 1909). Thus it could be concluded that the first year of life was the most decisive, and that this age period is very hard to deal with, as Chapin himself acknowledged (1908b).

The Speedwell Society expanded from its original location at Morristown to another at Yonkers, and then added a third, operated by the Free Synagogue of New York, to prepare abandoned children for adoption in Jewish homes. In 1916, Chapin noted that the City of New York in the previous decade had contributed nearly five million dollars to five institutions devoted to the care of infants; instead of spending such money on institutions, he argued that it would be better to use it to support a series of carefully regulated private homes (Chapin, 1916).

One morning in the spring of 1910, a baby girl wrapped in newspapers was found in Central Park by a policeman who gave her to Chapin, whose childless wife put her in the vacant nursery on the fourth floor of their home. Reluctantly, however, the Chapins decided they were too old to undertake the responsibility of rearing a child who would not be an adult until they had grown very old. They located a willing set of foster parents. Yet something had been started: the Chapins expanded the top floor of their home into a nursery, with a half dozen cribs that soon were filled with abandoned babies. The result of moving waifs into a better environment was an increase in their weight, health, and manifest happiness. As soon as the infants reached this stage, they were placed in permanent homes. Over a 5-year period, 98 "unpromising" babies passed through this upstairs nursery. It was then expanded into the Alice Chapin Adoption Nursery, which was operated under Chapin's philosophy that the sooner a child could be gotten healthy and put into a permanent home, the better for the child. Eventually this attitude was accepted by most of the adoption agencies in America. The number of lives thus saved from physiological and psychological damage can hardly be imagined. The Alice Chapin Nursery itself placed nearly 2,000 babies into good homes (see Chapin, 1920; Pease, 1957).

\section{Statistical Data on a Critical Period of Socialization}

Were this all that Henry Dwight Chapin had accomplished, he would have earned at least a small place in the annals of child psychology. ${ }^{1}$ But Chapin was a pioneer in yet another regard: he was one of the first scientists in this country to concern himself with the application of statistical data to child welfare.

Even as early as 1891 , Chapin was collecting statistics, some of them quite grim. Presenting his findings in 1894, Chapin noted that during the previous year, 3,042 children in New York city had been received at the morgue, and that 2,851 of them had been buried in Potter's Field, whereas by comparison only $10 \%$ of the city's adult dead had been buried there at the city's expense (Chapin, 1894).

Chapin published statistical data on 1,000 observed cases at his hospital, extending from March 1900 to March 1902, and on another 700 cases extending from March 1903 to March 1904, in which he was trying to ascertain the antecedent circumstances of each child admitted to the hospital. Some of this information can give us a conception of what was happening. Nearly all the parents existed on subsistence earnings; about $20 \%$ of the infants were from broken homes; only about half of the parents were judged in good health; only about a third could be said to be in the good category insofar as drinking habits were concerned. Of the 1,700 cases surveyed, 791 were from Catholic homes, 394 from Jewish homes, 196 from Protestant homes, and 282 from mixed homes; the remainder were not thus indicated (Chapin, 1905).

At the 1914 annual meeting of the American Association for Study and Prevention of Infant Mortality, Chapin drew attention to the high rate of death among institutionalized infants under 1 year of age, citing statistics gathered from 10 infant asylums located in different cities in the United States. Some of the other participants agreed with him. One of them pointed to an institution in Philadelphia where the mortality among infants under 1 year of age was $100 \%$, with no infant admitted under 1 year of age living to be 2 years old. Another participant added that of babies known to be born in institutions, only $8 \%$ died during the 1st month, but before the year was over, $48 \%$ had. Chapin noted that while the food and hygiene had been improved vastly in infant institutions, the heavy mortality rate still existed, double and even triple what it ought to be (Chapin, 1915).

In subsequent papers over the next decade, Chapin continued to supply statistical data indicating an age factor in mortality. In 1916, using the New York State Board 
Table 1

Death Rates, in percent, for $\mathbf{5 0 , 0 0 0}$ Children in New York Institutions, 1914-1915

\begin{tabular}{lcc}
\hline & \multicolumn{2}{c}{ Years } \\
\cline { 2 - 3 } Ages & 1914 & 1915 \\
\hline Under 3 months & 73 & 65 \\
3-6 months & 56 & 62 \\
6-12 months & 44 & 46 \\
1-2 years & 19 & 18 \\
2-5 years & 3 & 3 \\
\hline
\end{tabular}

of Charities figures, he showed that the fluctuations in the populations of institutions for children were following the relative average rate of increase in the population of New York State. The death rate in these institutions over 2 years are summarized in Table 1 .

These percentages were based on more than 50,000 children who were admitted to and discharged from New York institutions during the 2 years indicated (see Chapin, 1916). Control data from the outside situation would not be exactly equivalent, but the above figures can be seen in the context of the New York State death rate per 1,000 persons from 1909 to 1912 , which was only 87.4 (this figure is less than $9 \%$; it of course includes deaths that occurred within the institutions themselves.)

In a report before the 1917 meeting of the New York Academy of Medicine, Chapin (1917) presented further statistical data which indicated that it was not the length of time spent in the institute per se, but rather the age during which institutionalization occurred that was important. Chapin considered the most important factor to be the lack of individual attention, which under normal circumstances would reflect motherly love. Even among the Speedwell children the age factor in mortality held. Of the 266 admissions reported for a 1-year period between November 30, 1918 and December 31, 1919 at Morristown, and for a similar period at Yonkers, only 6 children died. Five of them were under the age of 6 months.

The evidence reported by Chapin was overwhelming: the 1st year of life was the most critical when normal conditions of rearing were replaced by a state of social deprivation, and the first 6 months were more important than the second 6 months (Chapin, 1911).

Henry Dwight Chapin remained active in research and published on the problems of children until he was in his middle 70's (see Chapin, 1915, 1923, 1932a, 1932b). When he retired from the directorship of his hospital unit in 1917, he and his wife took a trip to the Pacific coast and back. Nearly every night they stopped at a different home in which a Chapin Adoption Nursery child had been placed (Pease, 1957). Chapin died without issue in Bronxville on June 27, 1942 (Anon., 1944). But as long as we note that thousands of children, who otherwise would not have done so, lived because of him, then his dying without issue will remain merely a biological technicality of expression.

\section{REFERENCES}

Anonymous. (1944). Henry Dwight Chapin. National cyclopedia of American biography (Vol. 31, 439-441). New York: James T. White.

Chapin, H. D. (1892). The survival of the unfit. Popular Science Monthly, 41, 182-187.

Chapin, H. D. (1894). Child-study in the hospital-a record of six hundred cases. Forum, 17, 125-128.

ChapIN, H. D. (1905). The work of the babies' wards of the New York post-graduate hospital for convalescent children. Archives of Pediatrics, 22, 241-247.

ChapIN, H. D. (1908a). Hospital social services. Outlook, 90, 867.

Chapin, H. D. (1980b). A plan of dealing with atrophic infants and children. Archives of Pediatrics, 25, 491-496.

Chapin, H. D. (1909). A plan of dealing with weak infants and children. Survey Charities, 21, 1267-1270.

Chapin, H. D. (1911). The proper management of foundlings and neglected infants. Medical Record, 79, 283-288.

ChapIN, H. D. (1915). A plea for accurate statistics in infants' institutions. American Pediatric Society Transactions, 27, 180-185.

Chapin, H. D. (1916). A scheme of state control for dependent infants. Medical Record, 84, 1081-1084.

ChapiN, H. D. (1917). Systematized boarding out vs. institutional care for infants and young children. New York Medical Journal, 105, 1009-1011.

Chapin, H. D. (1920). Problems of boarding-out, with an attempted solution. Medical Record, 97, 677-681.

Chapin, H. D. (1923). Heredity and child culture. London: George Routledge.

ChapIN, H. D. (1932a). Convalescent care for hospital babies. Journal of the American Medical Association, 82A, 40-43.

ChapiN, H. D. (1932b). Foster homes for needy, sickly infants and little children. The Journal-Lancet, 52, 289-290.

EberTs, C. G., \& GraY, P. H. (1982). Evaluating the historical treatment of female psychologists of distinction using citation analysis and textbook coverage. Bulletin of the Psychonomic Society, 20, 7-10.

GARFIELD, E. (1979). Citation indexing: Its theory and application in science, technology, and humanities. New York: Wiley.

GRAY, P. H. (1958). Theory and evidence of imprinting in human infants. Journal of Psychology, 46, 155-166.

Gray, P. H., \& Gray, I. M. (1988, August). The hypothetico-deductive theory of imprinting applied to serial murder. Paper presented to the convention of the Animal Behavior Society, Missoula, Montana.

P[ease], M. C. (1942). Henry Dwight Chapin, M. D. American Journal Diseases of Children, 64, 535-538.

Pease, M. C. (1957). Henry Dwight Chapin (1857-1942). In B. S. Veeder (Ed.), Pediatric profiles (pp. 68-77). St. Louis: Mosby.

\section{NOTE}

1. This is the kind of problem to which citation analysis can be applied (Eberts \& Gray, 1982; Garfield, 1979). A search in the Science citation index and Social science citation index for references in the journal literature to Chapin has yielded the following array: From 1961 through 1970 , there were 4 citations, of which only one was in a psychological journal. From 1971 through 1980, there were 7 citations, only one of which was in a psychological journal. From 1981 to the present, there were 14 citations, none in a psychology journal. It would thus appear that Chapin is increasingly being noticed for his pioneer work in medicine and pediatrics, but not yet for his equally pioneering work in developmental psychology.

(Manuscript received June 7, 1988.) 